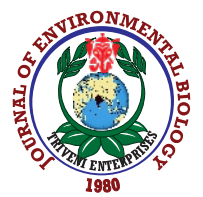

\title{
Biotization of tissue culture banana plantlets with Methylobacterium salsuginis to enhance the survival and growth under greenhouse and open environment condition
}

\author{
P. Pushpakanth', R. Krishnamoorthy ${ }^{2}$, R. Anandham ${ }^{1}$ and M. Senthilkumar ${ }^{1 *}$ \\ 'Department of Agricultural Microbiology, Tamil Nadu Agricultural University, Coimbatore-641 003, India \\ ${ }^{2}$ Department of Crop Management, Vanavarayar Institute of Agriculture, Pollachi- 642 103, India \\ *Corresponding Author Email : msenthilkumar@tnau.ac.in
}

\section{Abstract}

Aim: This study aimed to investigate the impact of M. salsuginis TNMB03 biotization on tissue culture banana cv. Grande Naine plantlets growth and survival under greenhouse and open environmental condition (exposed to direct sunlight).

\begin{abstract}
Methodology: Banana plantlets were transferred from culture flasks to protray and maintained under the greenhouse and open environmental condition for 30 days with or without M. salsuginis TNMB03 treatment. After 30 days, plant growth parameters like pseudostem height, girth, number of leaves, leaf area, fresh and dry biomass, root parameters, plantlet survival, chlorophyll a and b, total chlorophyll, carotenoids and soluble protein and Methylobacterium population in upper and lower surface of leaf, as well as endophytic population were assessed.
\end{abstract}

Results: This study showed that the plantlets biotized with M. salsuginis TNMB03 had better acclimatization response under both the experimental condition than that of uninoculated plantlets. Positive influence on the survival and growth of $M$. salsuginis TNMB03 biotized plantlets was observed when transferred directly to greenhouse and open environmental condition. Inoculation of $M$. salsuginis TNMB03 increased the plant height, girth and number of leaves, root length, lateral root and biomass in comparison to the uninoculated plantlets in greenhouse and open environment. Uninoculated plantlets kept under open environment had lower chlorophyll content and sun scorching damages compared to M. salsuginis TNMB03 inoculated plants, which had dark green leaves and increased chlorophyll content.

Interpretation: This study shows a new potential technique of using $M$. salsuginis TNMB03 in tissue culture plantlets, which can help in enhancing the growth of plantlets transferred from culture vessel to greenhouse or open environmental condition without undergoing the routine acclimatization procedure.

Key words: Banana, Biohardening, Biotization, Endophytes, Methylobacterium salsuginis

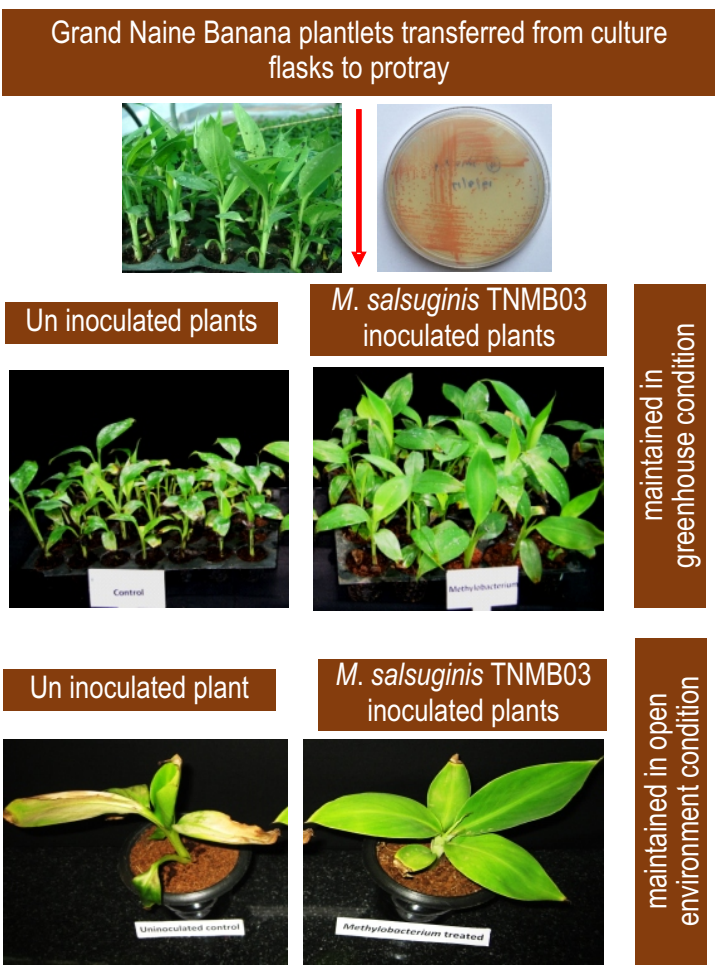

How to cite : Pushpakanth, P., R. Krishnamoorthy, R. Anandham and M. Senthilkumar: Biotization of tissue culture banana plantlets with Methylobacterium salsuginis to enhance the survival and growth under greenhouse and open environment condition. J. Environ. Biol., 42, 1452-1460 (2021). 


\section{Introduction}

The primary advantage of plant tissue culture technique lies in the production of uniform and high quality planting material that can be produced in a reduced area and time on a year-round basis under disease-free environment anywhere irrespective of the season and weather (Revathi et al., 2019). The large scale production technology is primarily based on in-vitro micropropagation in which rapid proliferation is accomplished from tiny stem cuttings, shoot tips or axillary buds as explants depending on the plant species. The advantage of micropropagation system can be fully appreciated only when the plantlets from the tissue-culture vessels transferred to the ex-vitro condition are successfully established. However, a large scale application of this technology is hindered by high mortality rate of micropropagated plantlets when transferred to ex-vitro conditions. One of the reason for high mortality of microshoots when transferred to ex-vitro conditions is that the cultured plants have nonfunctional stomata, weak root system and poorly developed cuticle (Mathur et al., 2008). In addition, microshoots, upon transfer to ex-vitro conditions are exposed to abiotic stress (altered temperature, light intensity and humidity conditions) and biotic stress conditions, i.e., soil microflora (Deb and Imchen, 2010).

Since last two decades, intensive investigation of plantassociated microorganisms, are significantly gaining scientific and commercial interest because of their prospective role in improving the plant quality and growth, and mitigating abiotic stresses. Researchers have attempted to use natural inhabitants of plants, epiphytes, endophytes and free living microorganisms to enhance adaptation of tissue culture propagules to environmental stresses (Gamez et al., 2019; Li et al., 2019). There is a great possibility for reintroduction of certain microorganisms or their combinations to tissue culture propagules, particularly bacteria. Enhanced abiotic resistance in response to some microbial bioinocualnts leading to developmental and physiological changes in the in-vitro derived plantlets is termed as biotization or biorpiming (Panigrahi et al., 2016). Jie et al. (2009) indicated that the re-introduction of naturally-occurring endophytes into tissue culture banana plantlets can improve the stress alleviation, plant growth and yield. Nowak and Shulaev (2003) reported that endophytes can be used as propagules priming agents, both as in-vitro culture and on transplanting phase. Azorhizobium caulinodans treated tissue cultures rice callus showed endophytic colonization in regenerated plantlets and increased plant protein content, nitrogen accumulation and yield (Senthilkumar et al., 2008).

The alpha proteobacterial genus Methylobacterium is constituted of methylotrophic bacteria, a group of Pink Pigmented Facultative Methylotrophs (PPFM) a potentially dominating and abundant colonizer of phyllosphere (Knief et al., 2010) which are able to interact symbiotically with different plant species, where they mainly occupy the inner tissues of the host, as endophytes. However, the degree of association with plants varies from rootnodulating symbionts (Madhaiyan et al., 2009), endophytic (Elbeltagy et al., 2000; Pirttilä et al., 2000; Karthi et al., 2017) and epiphytic (Omer et al., 2004) on plant surfaces. Methylobacterium sp. impart several beneficial effects on plant growth through direct or indirect mechanisms by producing of phytohormones such as cytokinins, auxins and vitamins (Koenig et al., 2002; Omer et al., 2004), that modulate plant growth (Senthilkumar et al., 2009; Meena et al., 2012), inducing higher photosynthetic activity (Cervantes et al., 2004), stimulate seed germination and involved in biological control of plant pathogen (Madhaiyan et al., 2004; Madhaiyan et al., 2006).

Considering the significance of Methylobacterium strain to stimulate plant cell differentiation and proliferation, the present study aimed to determine the ability of Methylobacterium salsuginis TNMBO3 in enhancing the survival, growth and biomass accumulation of tissue culture banana plantlets and acclimatization process under greenhouse and open environmental conditions.

\section{Materials and Methods}

Plant materials: In-vitro raised germ free tissue culture banana cultivar cv. Grande Naine (Musa acuminate) procured from Sun Glow Biotech, Coimbatore, Tamil Nadu, India was used for the experiment.

Microorganism and Biotization: Methylobactrium salsuginis TNMB03 (NCBI No. KT390764) was selected in the present study based on its plant growth promoting traits (Pushpakanth et al., 2016). The microbial culture was maintained in Ammonia Mineral Salt (AMS) medium supplemented with $0.5 \%$ methanol. Plantlets with three fully developed leaves and well-developed root system formed under in-vitro condition in tissue culture bottles were removed from the culture bottles and washed with sterile water before being transferred to individual micropots in a protray containing the substrate media mixture of cocopeat, vermicompost and vermiculite (Singh et al., 2011). Each treatment consisted twenty plantlets per protray per treatment. The experiment was arranged in completely randomized design (CRD) with four treatment and five replications were subjected to biotization. Biotization was done in two sets of environmental conditions with one set under existing procedure maintained by commercial tissue culture unit, i.e., $25 \pm 2^{\circ} \mathrm{C}$ with relative humidity of $68 \%$ under greenhouse condition and another one under open environment with direct exposure to sunlight with prevailing atmospheric temperature at $30 \pm 2^{\circ} \mathrm{C}$ (Gosal et al., 2010). The protrays were frequently sprayed with water to maintain $50 \%$ moisture. The experiment was conducted for 30 days to observe the physiological response, growth and survival of banana plantlets in response to $M$. salsuginis TNMB03 application. 
Bacterial culture preparation and inoculation: $M$. salsuginis TNMB03 was cultured in Ammonia Mineral Salt (AMS) medium supplemented with $0.5 \%$ methanol as described by Corpe (1985). The culture was incubated at room temperature for 10 days in a rotary shaker at $180 \mathrm{rpm}$ to get a higher cell population of $10^{10} \mathrm{cfu}$ $\mathrm{ml}^{-1}$. The cells were harvested by centrifugation at $8,000 \mathrm{rpm}$ for $15 \mathrm{~min}$. The pelleted cells were washed twice and resuspended in sterile phosphate buffer and adjusted to get $\mathrm{OD}$ value of 1.0 at 600 $\mathrm{nm}$ before imposing the treatment.

Plantlets were collected from tissue culture bottles and washed with sterile distilled water to remove the agar debris. Bacterial inoculation of plantlets was done as root dipping followed by foliar spray by diluting the inoculum in sterile distilled water at $1 \%$ concentration. For root dipping, prior to inserting the plantlets in protray, the roots were dipped in $200 \mathrm{ml}$ diluted bacterial suspension of M. salsuginis TNMB03 for $20 \mathrm{~min}$ followed by air dry for $5 \mathrm{~min}$. For foliar application, 10 to $15 \mathrm{ml}$ of bacterial suspension per plantlet was sprayed over the foliage on $10^{\text {th }}$ day after the plantlet establishment using a hand sprayer in the evening (after $4 \mathrm{pm}$ ) with uniform wetting. For the uninoculated control plantlets, roots and foliage were dipped and sprayed with sterile distilled water, respectively.

Assessment of growth of banana plantlets: Plant growth parameters like pseudostem height, girth, number of leaves, leaf area, fresh and dry biomass, root parameters like root length and number of lateral roots, percentage of plantlet survival, changes in the biochemical parameters like chlorophyll $a$ and $b$, total chlorophyll, carotenoids and soluble protein and Methylobacterium population in upper and lower surface of leaf, as well as endophytic population were assessed.

Two samplings were done with initial one before imposing the treatment ( $0^{\text {th }}$ day) and another on $30^{\text {th }}$ day of treatment. For each sampling, four plants were destructively harvested from each treatment for plant parameter analysis. Plant pseudostem height was measured from the collar region to the tip of the plant, stem diameter was measured using a thread, leaf area was calculated by the formula $L A=L \times B \times K \times N$ (Murray, 1960). Root length was determined by measuring the length of root from the base of the root to the tip of the longest root. The number of leaves per plant was obtained through physical counting. Plantlets dry biomass was obtained by drying in hot air oven at $60-70^{\circ} \mathrm{C}$ until a constant dry weight was obtained. The chlorophyll content and carotenoids were assayed according to Arnon (1971) method. The leaf soluble protein content was evaluated by Bradford (1976) method using bovine serum albumin as a standard. The absorbance was read on a spectrophotometer (Shimadzu, UV160A) at $625 \mathrm{~nm}$.

Fully expanded leaves were collected and the samples were handled aseptically for enumeration of Methylobacterium population. Epiphytic Methylobacterium population on both abaxial and adaxial surface of leaves was determined by leaf imprinting method (Corpe, 1985) on solidified ammonium mineral salt medium supplemented with $0.5 \%$ methanol and incubated at $30^{\circ} \mathrm{C}$ for $5-7$ days and the total population was calculated as number of colonies per $\mathrm{cm}^{2} \times$ leaf area $\left(\mathrm{cm}^{2}\right)$ and expressed in $\log _{10}$ cfu leaf ${ }^{1}$ whereas the endophytic population was estimated after surface sterilization and thoroughly crushed in a sterilized pestle and mortar followed by standard protocol of serial dilution and plating technique.

Statistical analyses: The data were analyzed by an analysis of variance (ANOVA) using the statistical analysis software (SAS). Means were compared using the value of least significant difference (LSD). Significant differences between measurements for different treatments were analyzed following LSD test $p<0.05$ was considered statistically significant. Principal Component Analysis (PCA) was performed for plant parameters using Rstudio software name (R-4.0.2) version software.

\section{Results and Discussion}

M. salsuginis TNMB03 was used as a biotization agent through seedling dipping and foliar application (1\% concentration) to $\mathrm{cv}$ Grande Naine plantlets to improve the survival rate by allowing the plantlets to grow under open condition (immediately after transfer to protray and exposing to direct sunlight) and another set of plantlets in greenhouse condition as practiced by the commercial tissue culture unit. Among the environmental conditions, the plantlets biohardened and kept under greenhouse condition showed significantly higher survival rate when compared to open environment condition followed by uninoculated control plantlets kept under greenhouse condition (Fig. 1A). The results also showed that the plantlets treated with M. salsuginis TNMB03 and exposed to open environment had better survival rate than the uninoculated plantlets kept under greenhouse for 30 days. Panigrahi et al. (2016) reported that about $10-40 \%(<70 \%)$ of the plantlets die or do not attain the market standard at weaning stage in the conventional technique. Acclimatization is normally difficult because water loss tends to be high from tender tissues, hence in most studies only $50-70 \%$ acclimatization of plantlets in the greenhouse was observed (Kumar et al., 2004; Kumar and Kanwar, 2005; Sousa et al., 2006).

Co-culturing of tissue culture plantlets with bacteria induces developmental and metabolic changes in the micropropagated plants which in turn enhance the abiotic stress tolerance. Prior transplanting the tissue culture plants to the field condition, application of microorganism, particularly endophytes is suggested at nursery stage (Ngamau et al., 2014). The production of plant growth hormones by the microbial inoculant play an important role in mitigating abiotic stress by improving root and shoot growth (Kargapolova et al., 2020). In addition, ACC deaminase production by the microbial isolate helps in reducing 

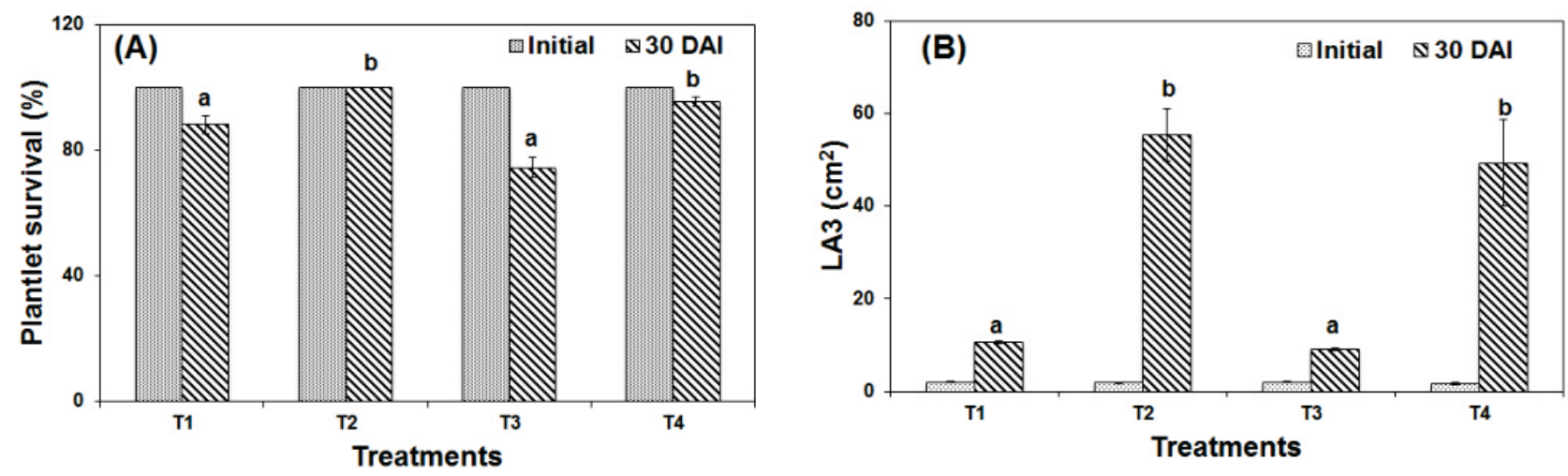

Fig. 1 : Effect of $M$. salsuginis TNMB03 on survival of banana plantlets for acclimatization (A) and Leaf area index of third leaf (B) Alphabets above the 30 DAl bar indicates statistical difference at $P<0.05$ and no significant differences was observed for initial measurement. T1 - Absolute control in greenhouse condition, T2 - M. salsuginis TNMB03 in greenhouse condition, T3 - Absolute control in open environment, T4 - M. salsuginis TNMB03 in open environment.

stress ethylene production by breaking down its precursor ACC and improves plantlets survival rate. This microbial mediated induced resistance response in micropropagated plants is referred as biotization. This experimental result shows that biotized plantlets with $M$. salsuginis TNMB03 had better acclimatization response than the uninoculated plantlets.

The plantlets treated with M. salsuginis TNMB03 showed a significant effect on leaf area. In general, the first leaf had higher leaf area followed by second and third leaf in treated plantlets, and it significantly increased with the advancement of plant growth in greenhouse and in open environment (Fig. 1B). It was also observed that the uninoculated plantlets in greenhouse condition had smaller leaf area, and the leaves were pale green color whereas the same plantlets exposed to open environment to direct sunlight, the leaves had scorching effect and were smaller in size. However, in biotized plantlets the leaves were larger, dark green color and there was no damage to the leaf due to high light intensity.

Plant growth promoting bacteria inoculation on improving banana plant growth and stress tolerance has been reported earlier (Ting et al., 2008; Jie et al., 2009; Panigrahi et al., 2016). Endophytic bacteria produces plant growth hormones such as auxins, cytokinin and gibberellic acid, that helps in improving banana plants height, pseudostem diameter and total number of leaves (Ting et al., 2008). In connection with this, in this study $M$. salsuginis TNMB03 treatment enhanced plant height, girth and number of leaves in both the environmental condition than the uninoculated plantlets under same growth condition after 30 day of inoculation. Higher plant height of $17.6 \mathrm{~cm}$ plant ${ }^{-1}$ was observed in plantlets kept under greenhouse condition, followed by plantlets kept under open environment (Table 1). Similarly, the plant girth was found to be highest in greenhouse condition followed by open environment with direct exposure to sunlight and least was observed in uninoculated plantlets kept under both the environmental condition (Table 1). Irrespective of the growth conditions, the banana plantlet growth had significantly $(P<0.05)$ improved in Methylobacterium.

The genus Methylobacterium have been studied for various plant growth promoting activities, and has been reported to positively influence the growth of various plants species (Krishnamoorthy et al., 2018; Poorniammal et al., 2020). Similar result was also observed in the present study where inoculation of M. salsuginis TNMB03 increased the plant height, girth and number of leaves, root length, lateral root and biomass in comparison to the uninoculated plantlets. Gamez et al. (2019) reported inoculation of Bacillus amyloliquefaciens Bs006 and Pseudomonas fluorescens Ps006 on banana plantlets growth improvement and higher biomass accumulation than that of control plants grown under greenhouse condition. The observed result of this study showed direct correlation between induced plant growth and number of leaves in the treated plantlets. This was observed in response to the production of phytohormones by M. salsuginis TNMB03, particularly due to high cytokinin synthesis in the plant tissues. Higher root length of $15.8 \mathrm{~cm}$ per plant was observed in plantlets grown under greenhouse condition followed by open environment (Table 2). Uninoculated plantlets had almost half the length of the roots when compared to treated plantlets after 30 days of growth. Similar results were also observed in the formation of lateral root. The number of lateral roots emerged per plant was more in treated plantlets than the uninoculated plantlets. The lateral root emergence per plant was highest in greenhouse condition (11 no. plant $^{-1}$ ) (Table 2).

The increase in fresh and dry weight of banana platelets in greenhouse and in open environment condition in this study revealed that $M$. salsuginis TNMB03 stimulated photosynthesis efficiency in-vitro plantlets. In addition, the increase in biomass of plantlets under open environment conditions which is almost on par with green house condition was also observed (Table 2). It is 
Table 1 : Influence of M. salsuginis TNMB03 biotization on plant height, girth and number of leaves in Grand Naine plantlets

\begin{tabular}{|c|c|c|c|c|c|c|}
\hline \multirow[t]{2}{*}{ Treatments } & \multicolumn{2}{|c|}{ Plant height (cm per plant) } & \multicolumn{2}{|c|}{ Plant girth (cm per plant) } & \multicolumn{2}{|c|}{ No. of leaves per plant } \\
\hline & Initial & 30 DAI & Initial & 30 DAl & Initial & 30 DAl \\
\hline \multicolumn{7}{|l|}{ Greenhouse condition } \\
\hline $\mathrm{T}_{1}$-Absolute control & $11.14 \pm 0.19^{\mathrm{a}}$ & $12.3 \pm 0.24^{b}$ & $0.56 \pm 0.02^{a}$ & $0.80 \pm 0.03^{b}$ & $3.80 \pm 0.20^{\mathrm{a}}$ & $4.00 \pm 0.32^{\mathrm{a}}$ \\
\hline $\mathrm{T}_{2}-$ M. salsuginis TNMB03 & $11.36 \pm 0.17^{\mathrm{a}}$ & $17.6 \pm 0.47^{\mathrm{a}}$ & $0.56 \pm 0.02^{\mathrm{a}}$ & $1.20 \pm 0.04^{\mathrm{a}}$ & $4.00 \pm 0.00^{\mathrm{a}}$ & $4.60 \pm 0.24^{a}$ \\
\hline \multicolumn{7}{|l|}{ Open environment } \\
\hline $\mathrm{T}_{3}$-Absolute control & $11.10 \pm 0.13^{\mathrm{a}}$ & $12.4 \pm 0.25^{b}$ & $0.52 \pm 0.02^{\mathrm{a}}$ & $0.82 \pm 0.04^{b}$ & $3.80 \pm 0.20^{\mathrm{a}}$ & $4.00 \pm 0.32^{\mathrm{a}}$ \\
\hline $\mathrm{T}_{4}-$ M. salsuginis TNMB03 & $11.32 \pm 0.22^{\mathrm{a}}$ & $16.5 \pm 0.50^{\mathrm{a}}$ & $0.54 \pm 0.02^{\mathrm{a}}$ & $1.17 \pm 0.02^{\mathrm{a}}$ & $4.00 \pm 0.00^{\mathrm{a}}$ & $4.80 \pm 0.20^{\mathrm{a}}$ \\
\hline
\end{tabular}

Each value represents mean of 20 replicates \pm SE. In the same column, significant differences according to $L S D$ at $P=0.05$ levels are indicated by different letters. The values are means of 10 plantlets per replication DAI - Days after inoculation

Table 2 : Grande Naine plantlets root growth and biomass under two different growth conditions when biotized with M. salsuginis TNMB03

\begin{tabular}{|c|c|c|c|c|c|c|c|c|}
\hline \multirow[t]{2}{*}{ Treatments } & \multicolumn{2}{|c|}{$\begin{array}{l}\text { Root length } \\
\left(\mathrm{cm}_{\text {plant }}{ }^{-1}\right)\end{array}$} & \multicolumn{2}{|c|}{$\begin{array}{l}\text { Lateral roots } \\
\text { (No. plant }{ }^{-1} \text { ) }\end{array}$} & \multicolumn{2}{|c|}{$\begin{array}{l}\text { Total fresh weight } \\
\left.\text { (g plant }{ }^{-1}\right)\end{array}$} & \multicolumn{2}{|c|}{$\begin{array}{l}\text { Total dry weight } \\
\quad\left(\text { g plant }^{-1}\right)\end{array}$} \\
\hline & Initial & $30 \mathrm{DAl}$ & Initial & $30 \mathrm{DAl}$ & Initial & $30 \mathrm{DAl}$ & Initial & $30 \mathrm{DAl}$ \\
\hline \multicolumn{9}{|l|}{ Greenhouse condition } \\
\hline $\mathrm{T}_{1}$-Absolute control & $4.84 \pm 0.12^{\mathrm{a}}$ & $8.58 \pm 0.13^{b}$ & $3.80 \pm 0.37^{\mathrm{a}}$ & $7.40 \pm 0.24^{b}$ & $1.19 \pm 0.022^{\mathrm{a}}$ & $1.27 \pm 0.012^{b}$ & $0.03 \pm 0.002^{\mathrm{a}}$ & $0.05 \pm 0.001^{b}$ \\
\hline $\mathrm{T}_{2}-$ M. salsuginis TNMB03 & $4.78 \pm 0.10^{\mathrm{a}}$ & $15.8 \pm 0.25^{\mathrm{a}}$ & $3.80 \pm 0.20^{\mathrm{a}}$ & $11.0 \pm 0.45^{\mathrm{a}}$ & $1.20 \pm 0.013^{\mathrm{a}}$ & $1.78 \pm 0.053^{\mathrm{a}}$ & $0.03 \pm 0.002^{\mathrm{a}}$ & $0.06 \pm 0.002^{\mathrm{a}}$ \\
\hline \multicolumn{9}{|l|}{ Open environment } \\
\hline $\mathrm{T}_{3}$-Absolute control & $5.04 \pm 0.07^{\mathrm{a}}$ & $8.62 \pm 0.18^{b}$ & $4.40 \pm 0.24^{\mathrm{a}}$ & $7.40 \pm 0.40^{b}$ & $1.15 \pm 0.015^{\mathrm{a}}$ & $1.29 \pm 0.016^{b}$ & $0.03 \pm 0.001^{\mathrm{a}}$ & $0.05 \pm 0.002^{b}$ \\
\hline $\mathrm{T}_{4}-$ M. salsuginis TNMB03 & $5.00 \pm 0.11^{\mathrm{a}}$ & $15.7 \pm 0.18^{\mathrm{a}}$ & $4.00 \pm 0.32^{\mathrm{a}}$ & $10.4 \pm 0.24^{a}$ & $1.17 \pm 0.015^{a}$ & $1.72 \pm 0.046^{a}$ & $0.03 \pm 0.002^{\mathrm{a}}$ & $0.06 \pm 0.002^{\mathrm{a}}$ \\
\hline
\end{tabular}

Each value represents mean of 20 replicates $\pm S E$. In the same column, significant differences according to $L S D$ at $P=0.05$ levels are indicated by different letters. The values are means of 10 plantlets per replication DAI - Days after inoculation

also possible that, plants with more number of leaf and higher chlorophyll per unit of foliar fresh weight would perform more net photosynthesis, hence plants accumulated more dry matter. PCA analysis showed the positive impact on total number of leafs, dry weight, chlorophyll and protein content in banana plants acclimatized in open environment (Fig. 2). Application of $M$. salsuginis TNMB03 to the plantlets under greenhouse conditions and open environment had increased the total fresh weight and dry weight of plantlets (Table 2). The higher fresh weight was observed under greenhouse condition with an increase of $40 \%$ over control followed by plantlets grown under open environment that had a fresh weight of $1.72 \mathrm{~g}$ per plant whereas the total dry weight was highest in treated plants grown under both conditions while the least was observed in uninoculated control.

The photosynthetic efficiency was measured in terms of Chla, Chlb, total chlorophyll and carotenoid concentration. The Chla content estimated at $30 \mathrm{DAl}$ with $\mathrm{M}$. salsuginis TNMB03 was $0.55 \mathrm{mg} \mathrm{g}^{-1}$ fresh leaf in plantlets grown under open environment followed by plantlets under greenhouse condition (Table 3). Similar result was also observed for Chlb and total chlorophyll content. Likewise, the carotenoid pigment content was significantly higher in $M$. salsuginis TNMB03 treated plantlets than the untreated plantlets grown under both conditions.
Generally transfer of tissue culture plantlets from in-vitro to ex-vitro conditions under direct sunlight may cause photoinhibition and chlorophyll photobleaching which was observed in Calathea louisae and Spathiphyllum floribundum plantlets when exposed to high irradiance immediately after transplantation (Van Huylenbroeck et al., 1995). However, the results of this study contradicted to the above reports. In the present study, there was no such damage to the photosynthetic pigments or yellowing of leaves. The results showed that the plantlets treated with M. salsuginis TNMB03 had dark green leaves. It is hypothesized that the photosynthetic apparatus are protected from direct sunlight and the structure and function are maintained due to the availability of cytokinin synthesized by the leaf residing M. salsuginis TNMB03 in treated plantlets. Cytokinin maintains the structure and function of photosynthetic apparatus under stress conditions (Chernyad'ev, 2009).

The highest mean soluble protein content was recorded in plantlets grown under open environment and lowest soluble protein content was registered under same growth conditions of untreated plantlets (Table 3). Irrespective of the growth condition, Methylobacterium inoculation had significantly improved the soluble protein content significantly. Kalyaeva et al. (2003) reported that colonization of Methylobacterium sp. N1 increased 


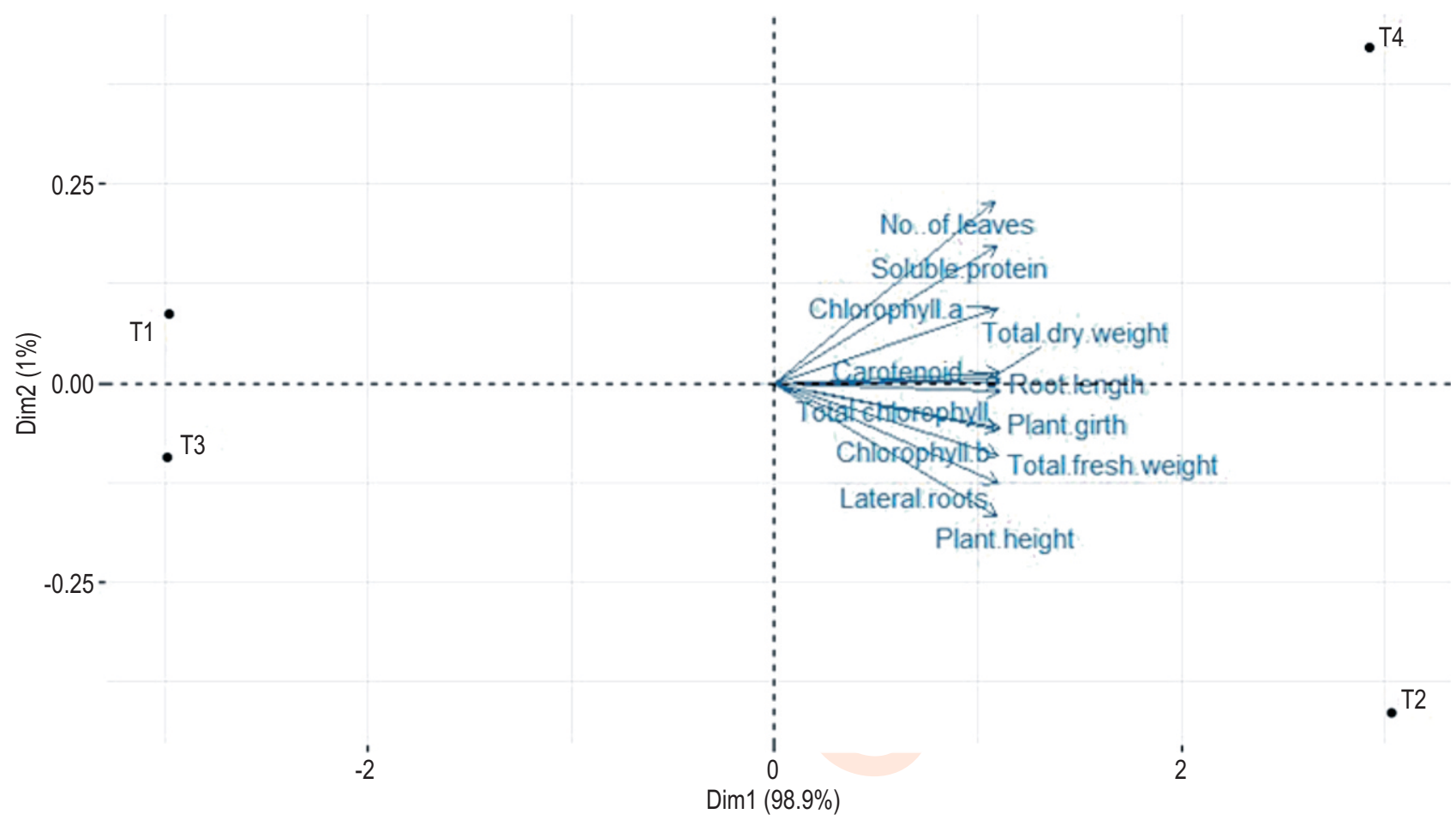

Fig. 2 : Principal component biplot of $M$. salsuginis TNMB03 treated banana plant parameters. T1 - Absolute control in greenhouse condition; T2 - $M$. salsuginis TNMB03 in greenhouse condition; T3-Absolute control in open environment and T4 - M. salsuginis TNMB03 in open environment.

Table 3 : Effect of M. salsuginis TNMB03 on biochemical parameters in Grand Naine tissue culture seedlings

\begin{tabular}{|c|c|c|c|c|c|c|c|c|c|c|}
\hline \multirow[t]{2}{*}{ Treatments } & \multicolumn{2}{|c|}{$\begin{array}{l}\text { Chlorophyll a } \\
\left(\mathrm{mg} \mathrm{g}^{-1}\right)\end{array}$} & \multicolumn{2}{|c|}{$\begin{array}{l}\text { Chlorophyll b } \\
\left(\mathrm{mg} \mathrm{g}^{-1}\right)\end{array}$} & \multicolumn{2}{|c|}{$\begin{array}{l}\text { Total chlorophyll } \\
\qquad\left(\mathrm{mg} \mathrm{g}^{-1}\right)\end{array}$} & \multicolumn{2}{|c|}{$\begin{array}{l}\text { Carotenoid } \\
\left(\mathrm{mg} \mathrm{g}^{-1}\right)\end{array}$} & \multicolumn{2}{|c|}{$\begin{array}{c}\text { Soluble protein } \\
\left(\mathrm{mg} \mathrm{g}^{-1}\right)\end{array}$} \\
\hline & Initial & $30 \mathrm{DAl}$ & Initial & $30 \mathrm{DAl}$ & Initial & $30 \mathrm{DAl}$ & Initial & $30 \mathrm{DAl}$ & Initial & $30 \mathrm{DAl}$ \\
\hline \multicolumn{11}{|l|}{ Greenhouse condition } \\
\hline $\mathrm{T}_{1}$-Absolute control & $\begin{array}{l}0.41 \\
\pm 0.003^{\mathrm{a}}\end{array}$ & $\begin{array}{l}0.42 \\
\pm 0.008^{b}\end{array}$ & $\begin{array}{l}0.14 \\
\pm 0.005^{a}\end{array}$ & $\begin{array}{l}0.24 \\
\pm 0.004^{\mathrm{b}}\end{array}$ & $\begin{array}{l}0.56 \\
\pm 0.004^{\mathrm{a}}\end{array}$ & $\begin{array}{l}0.67 \\
\pm 0.012^{\mathrm{b}}\end{array}$ & $\begin{array}{l}0.02 \\
\pm 0.002^{\mathrm{a}}\end{array}$ & $\begin{array}{l}0.04 \\
\pm 0.002^{\mathrm{b}}\end{array}$ & $\begin{array}{l}8.23 \\
\pm 0.602^{\mathrm{a}}\end{array}$ & $\begin{array}{l}10.73 \\
\pm 0.278^{b}\end{array}$ \\
\hline $\mathrm{T}_{2}-$ M. salsuginis TNMB03 & $\begin{array}{l}0.41 \\
\pm 0.003^{\mathrm{a}}\end{array}$ & $\begin{array}{l}0.54 \\
\pm 0.006^{\mathrm{a}}\end{array}$ & $\begin{array}{l}0.16 \\
\pm 0.005^{\mathrm{a}}\end{array}$ & $\begin{array}{l}0.38 \\
\pm 0.004^{a}\end{array}$ & $\begin{array}{l}0.57 \\
\pm 0.003^{\mathrm{a}}\end{array}$ & $\begin{array}{l}0.92 \\
\pm 0.007^{\mathrm{a}}\end{array}$ & $\begin{array}{l}0.02 \\
\pm 0.004^{\mathrm{a}}\end{array}$ & $\begin{array}{l}0.24 \\
\pm 0.005^{\mathrm{a}}\end{array}$ & $\begin{array}{l}8.25 \\
\pm 0.219^{\mathrm{a}}\end{array}$ & $\begin{array}{l}13.22 \\
\pm 0.151^{\mathrm{a}}\end{array}$ \\
\hline \multicolumn{11}{|l|}{ Open environment } \\
\hline $\mathrm{T}_{3}$-Absolute control & $\begin{array}{l}0.41 \\
\pm 0.002^{\mathrm{a}}\end{array}$ & $\begin{array}{l}0.40 \\
\pm 0.003^{c}\end{array}$ & $\begin{array}{l}0.16 \\
\pm 0.002^{\mathrm{a}}\end{array}$ & $\begin{array}{l}0.25 \\
\pm 0.007^{\mathrm{b}}\end{array}$ & $\begin{array}{l}0.57 \\
\pm 0.004^{\mathrm{a}}\end{array}$ & $\begin{array}{l}0.66 \\
\pm 0.004^{b}\end{array}$ & $\begin{array}{l}0.02 \\
\pm 0.002^{\mathrm{a}}\end{array}$ & $\begin{array}{l}0.05 \\
\pm 0.001^{\mathrm{b}}\end{array}$ & $\begin{array}{l}8.23 \\
\pm 0.461^{a}\end{array}$ & $\begin{array}{l}10.53 \\
\pm 0.162^{b}\end{array}$ \\
\hline $\mathrm{T}_{4}-$ M. salsuginis TNMB03 & $\begin{array}{l}0.41 \\
\pm 0.002^{\mathrm{a}}\end{array}$ & $\begin{array}{l}0.55 \\
\pm 0.003^{\mathrm{a}}\end{array}$ & $\begin{array}{l}0.15 \\
\pm 0.003^{\mathrm{a}}\end{array}$ & $\begin{array}{l}0.37 \\
\pm 0.006^{\mathrm{a}}\end{array}$ & $\begin{array}{l}0.57 \\
\pm 0.005^{\mathrm{a}}\end{array}$ & $\begin{array}{l}0.91 \\
\pm 0.003^{\mathrm{a}}\end{array}$ & $\begin{array}{l}0.02 \\
\pm 0.002^{\mathrm{a}}\end{array}$ & $\begin{array}{l}0.24 \\
\pm 0.002^{\mathrm{a}}\end{array}$ & $\begin{array}{l}8.23 \\
\pm 0.362^{\mathrm{a}}\end{array}$ & $\begin{array}{l}13.78 \\
\pm 0.162^{\mathrm{a}}\end{array}$ \\
\hline
\end{tabular}

Each value represents mean of 20 replicates \pm SE. In the same column, significant differences according to $L S D$ at $P=0.05$ levels are indicated by different letters. The values are means of 10 plantlets per replication DAI - Days after inoculation.

the total content of pigments and soluble proteins in the leaves of regenerated wheat plants. Here also, the carotenoid and soluble protein content was increased under the influence of $M$. salsuginis TNMB03 in the leaves of colonized tissue culture banana seedlings when compared to uncolonized seedlings in greenhouse and open environmental conditions. Carotenoids also provide protection from UV radiation, because they can transform UV energy into visible light. Increase in the carotenoid content of leaves may also contribute to dark green leaves when compared to pale green leaves in uninoculated plantlets, which further ensures that cytokinin will maintains the structure and function of the photosynthetic apparatus under stress conditions (Chernyad'ev, 2009).

Assessing population of Methylobacterium in the treatments revealed that there was a significant differences in the 

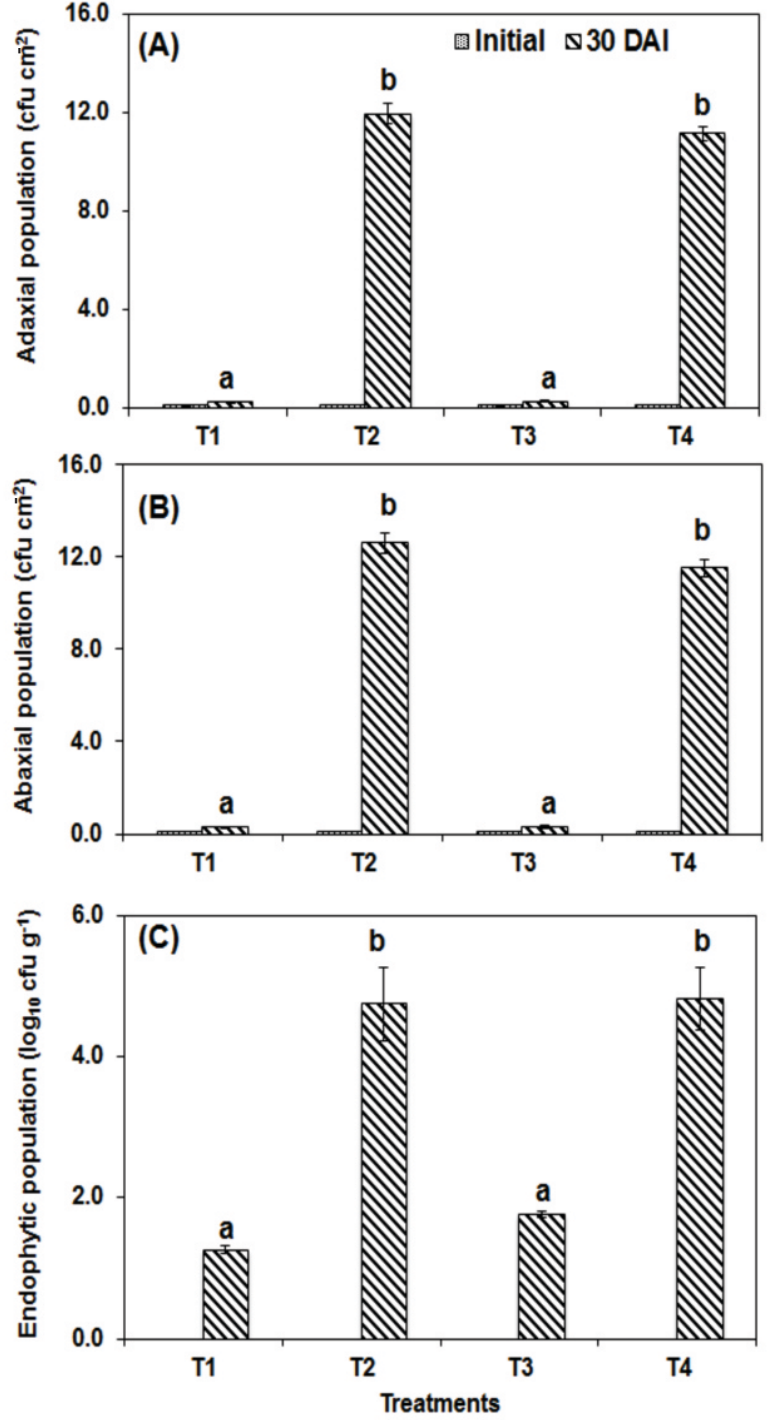

Fig. 3 : Effect of M. salsuginis TNMB03 on epiphytic and endophytic population in banana plantlets for acclimatization. A-Adaxial; B - Abaxial and $\mathrm{C}$ - Endophytic population. Alphabets above the 30DAl bar indicates statistical difference at $\mathrm{P}<0.05$ and no significant differences was observed for initial measurement. T1 - Absolute control in greenhouse condition; T2 - M. salsuginis TNMB03 in greenhouse condition, T3 Absolute control in open environment and T4 - M. salsuginis TNMB03 in open environment.

leaf epiphytic population both in adaxial and abaxial leaf surface and as leaf endophytes. Methylobacterium spp. is one of the dominant microbial community that colonize the plant phyllosphere and endosphere (Pirttilä et al., 2005). The survivability of germ free banana plantlets under open environment and in greenhouse is mainly due to the influence of Methylobacterium which can mitigate the plantlets against abiotic stress. In this study, survivability of Methylobacterium in the leaves of treated banana plantlets after 30 DAl showed successful colonization in the leaves both as epiphytes and endophytes. When the treated plantlets were analyzed for the survival of Methylobacterium, significant differences were observed in the population of Methylobacterium in adaxial surface of plantlets grown under greenhouse condition.

Further, the treated plants showed no visible symptoms of sun scorching effect on leaves which was observed in the untreated plants. The protection of leaf damage from direct sunlight / leaf senescence may be due to the synthesis and upregulation of antioxidant genes, causing decomposition of reactive oxygen species induced by heat stress (Rivero et al., 2007). Among the treatments, greenhouse grown plantlets recorded higher population in the adaxial surface of leaf followed by plantlets grown under open environment and the least was observed in uninoculated plants. Likewise, the abaxial population was also found to be higher in greenhouse condition followed by open environment (Fig. 3). Similarly, the endophytic population was also higher in treated plants compared to uninoculated plantlets. Further, it also revealed that the M. salsuginis TNMB03 treated plantlets did not show any malformation in plantlets growth. As Methylobacterium-plant association in the phyllosphere is not highly genotype-specific (Knief et al., 2010) and this demonstrates the potential of this microbial agent to be used as a bioinoculant for wide range of crops.

Manipulation of acclimatization conditions prior to or upon transplanting may reduce the loss (Van-Huylenbroeck and Debergh, 1996), however, at added cost to the producer. Transfer of tissue culture plants directly to polybags for hardening and acclimatization may not be successful due to transplantation shock leading to heavy mortality during weaning period. Under this perspective, an alternative system that reduces the cost of processing as well as time taken for gradual acclimatization is of fundamental importance. Hence, some researchers have reached for natural inhabitants of plants, epiphytes and endophytes, to enhance the adaptation of tissue culture propagules to environmental stresses. Enhanced abiotic resistance in response to microbial inoculant(s) leading to developmental and physiological changes in the in-vitro culture derived plantlets has been referred to as 'biotization' or 'biopriming' (Panigrahi et al., 2016). Regardless of the experimental condition (greenhouse and open environment), all M. salsuginis TNMB03 treated plantlets in this study showed similar morphological and vegetative growth. This is the first report of successful use of Methylobacterium sp. for acclimatization of tissue culture plantlets without the need for greenhouse. In-vitro grown banana plantlets established in greenhouse and open environmental conditions were also not cross contaminated. Microbial contamination by fungi and bacteria can increase the costs of micropropagation (Purohit et al., 2011).

Methylobacterium spp. are the important microbial partner of many plants and it plays an important role in plant stress mitigation through various mechanisms. This specific plant 
stress mitigating character is much in need for any tissue culture plants for successful establishment in main field condition. In this study, M. salsuginis TNMB03 biotized plantlets had enhanced survival rate, plant growth and development which are comparable under both experimental conditions. Hence, this technique may be extended to other high value commercial plants which are developed under tissue culture technique.

\section{Acknowledgment}

This study was supported by a grant from the Science Engineering Research Board, New Delhi, India, under the FastTrack Young Scientist category.

\section{Add-on Information}

Author's contribution : P. Pushpakanth: Performed scientific experiments; R. Krishnamoorthy: Data analyzing, Manuscript Drafting; R. Anandham: Conceptualization of the study Manuscript Drafting, Data analysing; M. Senthilkumar: Conceptualization of the study, Guided Pushpakanth in performing the experiment Manuscript drafting.

Research content : The research content of manuscript is original and has not been published elsewhere.

Ethical approval : NotApplicable

Conflict of interest : The authors declare that there is no conflict of interest.

\section{Data from other sources : NotApplicable}

Consent to publish : All authors agree to publish the paper in Journal of Environmental Biology.

\section{Reference}

Arnon, D.I.: The light reactions of photosynthesis. PNAS, 68, 2833-2892 (1971).

Bradford, M.M.: A rapid and sensitive method for the quantitation of microgram quantities of protein utilizing the principle of proteindye binding. Anal. Biochem., 72, 248-254 (1976).

Cervantes, M.J., S. Lopez-Diaz and B. Rodriguez-Garay: Detection of the effects of Methylobacterium in Agave tequilana Weber var. azul by laser-induced fluorescence. Plant Sci., 166, 889-892 (2004).

Chernyad'ev, I.I.: The protective action of cytokinins on the photosynthetic machinery and productivity of plants under stress. Appl. Biochem. Microbiol., 45, 351-362 (2009).

Corpe, W.A.: A method for detecting methylotrophic bacteria on solid surfaces. J. Microbiol. Methods., 3, 215-221 (1985).

Deb, C.R. and T. Imchen: An efficient in vitro hardening of tissue culture raised plants. Biotech., 9, 79-83 (2010).

Elbeltagy, A., K. Nishioka, H. Suzuki, T. Sato, Y.I. Sato, H. Morisaki, H. Mitsui and K. Minamisawa: Isolation and characterization of endophytic bacteria from wild and traditionally cultivated rice varieties. Soil Sci. Plant Nutr., 46, 617-629 (2000).
Gamez, R.M., F. Rodríguez, N.M. Vidal, S. Ramirez, R.V. Alvarez, D. Landsman and L. Mariño-Ramírez: Banana (Musa acuminata) transcriptome profiling in response to rhizobacteria: Bacillus amyloliquefaciens Bs006 and Pseudomonas fluorescens Ps006. BMC Genomics, 20, 378. https://doi.org/10.1186/s12864-0195763-5(2019).

Gosal, S.K., A. Karlupia, S.S. Gosal, I.M. Chhibba and A. Varma: Biotization with Piriformospora indica and Pseudomonas fluorescens improves survival rate, nutrient acquisition, field performance and saponin content of micropropagated Chlorophytum sp. Indian J. Biotechnol., 9, 289-297 (2010).

Jie, L., W. Zifeng, C. Lixiang, T. Hongming, I. Patrik, J. Zide and Z. Shining: Artificial inoculation of banana tissue culture plantlets with indigenous endophytes originally derived from native banana plants. Biol. Control, 51, 427-434 (2009).

Karthi, M., P. Pushpakanth, R. Krishnamoorthy and M. Senthilkumar: Endophytic bacteria associated with banana cultivars and their inoculation effect on plant growth. J. Hortic. Sci. Biotech., 92, 568-576 (2017).

Kalyaeva, M.A., E.G. Ivanova, N.V. Doronina, N.S. Zakharchenko, Y.A. Trotsenko and Y.I. Buryanov: The effect of aerobic methylotrophic bacteria on the in-vitro morphogenesis of soft wheat (Triticum aestivum). Russ. J. Plant Physiol., 50, 313-317 (2003).

Knief, C., L. Frances and J.A. Vorholt: Competitiveness of diverse Methylobacterium strains in the phyllosphere of Arabidopsis thaliana and identification of representative models, including $M$. extorquens PA1. Microb. Ecol., 60, 440-452 (2010).

Koenig, R.L., R.O. Morris and J.C. Polacco: tRNA is the source of lowlevel transzeatin production in Methylobacterium spp. J. Bacteriol., 184, 1832-1842 (2002).

Kargapolova, K.Y., G.L. Burygin, O.V. Tkachenko, N.V. Evseeva, Y.V. Pukhalskiy and A.A. Belimov: Effectiveness of inoculation of in vitro-grown potato microplants with rhizosphere bacteria of the genus Azospirillum. Plant Cell Tiss. Organ Cult., 141, 351-359 (2020).

Krishnamoorthy, R., S.W. Kwon, K. Kumutha, M. Senthilkumar, S. Ahmed, T. Sa and R. Anandham: Diversity of culturable methylotrophic bacteria in different genotypes of groundnut and their potential for plant growth promotion. 3Biotech., 8, 275 (2018).

Kumar, S. and J.K. Kanwar: Plant regeneration from callus and cell suspension cultures of Gerbera jamesonii Diablo. Eur. J. Hort. Sci., 70, 265-270 (2005).

Kumar, S., J.K. Kanwar and D.R. Sharma: In-vitro regeneration of Gerbera jamesonii from leaf and petiole explants. J. Plant Biochem. Biotechnol., 13, 73-75 (2004).

Li, D., R.A. Mensah, F. Liu, N. Tian, Q. Qi, K.W. Yeh, X. Xuhan, C. Cheng and Z. Lai: Effects of Piriformospora indica on rooting and growth of tissue-cultured banana (Musa acuminata cv. Tianbaojiao) seedlings. Sci. Hortic-Amsterdam., 257, 108649 (2019).

Madhaiyan, M., S. Poonguzhali, M. Senthilkumar, H. Chung, J. Yang, S.P. Sundaram and T Sa: Growth promotion and induction of systemic resistance in rice cultivar Co-47 (Oryza sativa L.) by Methylobacterium spp. Botanical Studies (Bulletin Acadamia Sinica)., 45, 315-324 (2004).

Madhaiyan, M., B.V. Suresh Reddy, R. Anandham, M. Senthilkumar, S. Poonguzhali, S.P. Sundaram and T. Sa: Plant growth-promoting Methylobacterium induces defense responses in groundnut (Arachis hypogaea L.) compared with rot pathogens. Curr. Microbiol., 53, 270-276 (2006). 
Madhaiyan, M., S. Poonguzhali, M. Senthilkumar, S.P. Sundaram and T. Sa: Nodulation and plant-growth promotion by methylotrophic bacteria isolated from tropical legumes. Microbiol. Res., 164, 114120 (2009).

Mathur, A., A.K. Mathur, P. Verma, S. Yadav, M.L. Gupta and M.P. Darokar: Biological hardening and genetic fidelity testing of microcloned progeny of Chlorophytum borivilianum. African J. Biotech., 7, 1046-1053 (2008).

Meena, K.K., M. Kumar, M.G. Kalyuzhnaya, M.S. Yandigeri, D.P. Singh, A.K. Saxena and D.K. Arora: Epiphytic pink-pigmented methylotrophic bacteria enhance germination and seedling growth of wheat (Triticum aestivum) by producing phytohormone. Anton. Leeuw. Int. J. G., 101, 777-786 (2012).

Murray, D.B.: The effect of deficiencies of the major nutrients on growth and leaf analysis of the banana. J. Trop. Agric., 37, 97-106 (1960).

Ngamau, C.N., V.N. Matiru, A. Tani and C.W. Muthuri: Potential use of endophytic bacteria as biofertilizer for sustainable banana (Musa sp.) Production. Afr. J. Horti. Sci., 8, 1-11 (2014).

Nowak, J. and V. Shulaev: Priming for Transplant Stress Resistance in In vitro Propagation. In Vitro Cell. Dev. Biol. Plant., 39, 107-124 (2003).

Omer, Z.S., R. Tombolini, A. Broberg and B. Gerhardson: Indole-3-acetic acid production by pink-pigmented facultative methylotrophic bacteria. Plant Growth Regul., 43, 93-96 (2004).

Panigrahi, S., K. Aruna Lakshmi, V. Madhuri and A.N. Soumya: Acclimatization of $I n$-vitro propagated banana grand naine by biotinization-Survival rate by phenol concentrations. In: Next Generation DNA Led Technologies (Eds.: S. Avadhanam, G. Jyothsna and A. Kashyap). Springer Briefs in Applied Sciences and Technology. Springer, Singapore, pp. 105-112 (2016).

Pati, R., M. Mishra, R. Chandra and M. Muthukumar: Histological and biochemical changes in Aegle marmelos Corr. before and after acclimatization. Tree Genet. Mol. Breed., 3, 1 (2013).

Pirttilä, A.M., H. Laukkanen, H. Pospiech, R. Myllylä and A. Hohtola: Detection of intracellular bacteria in the buds of Scotch pine (Pinus sylvestris L.) by in-situ hybridization. Appl. Environ. Microbiol., 66, 3073-3077 (2000).

Pirttilä, A.M., H. Pospiech, H. Laukkanen, R. Myllylä and A. Hohtola: Seasonal variations in location and population structure of endophytes in buds of Scots pine. Tree Physiol., 25, 289-297 (2005).

Poorniammal, R., M. Senthilkumar, S. Prabhu and K. Anandhi: Effect of Methylobacterium on seed germination, growth and yield of barnyard millet (Echinochloa frumentacea var. COKV 2) under rainfed condition. J. Pharmacogn. Phytochem., 9, 1675-1677 (2020)
Pushpakanth, P., K. llamurugu and M. Senthilkumar: Characterization of endophytic plant growth promoting traits of Methylobacterium sp. isolated from banana (Musa sp.). Int. J. Fore. Crop Improv., 7, 114120 (2016).

Purohit, S.D., J.A. Teixeira da Silva and N. Habibi: Current approaches for cheaper and better micropropagation technologies. Int. J. Plant Dev. Biol., 5, 1-36 (2011).

Revathi, S., N. Sivakumaran, D. Ramajayam, M.S. Saraswathi, S. Backiyarani and S. Umas: Growth estimation during hardening phase of tissue cultured banana plantlets using bootstrapped artificial neural network. J. Environ. Biol., 40, 719-724 (2019).

Rivero, R.M., M. Kojima, A. Gepstein, H. Sakakibara, R. Mittler, S. Gepstein and E. Blumwald: Delayed leaf senescence induces extreme drought tolerance in a flowering plant. PNAS, 104, 19631-19636 (2007).

Senthilkumar, M., M. Madhaiyan, S.P. Sundaram, H. Sangeetha and S. Kannaiyan: Induction of endophytic colonization in rice (Oryza sativa L.) tissue culture plants by Azorhizobium caulinodans. Biotechnol. Lett., 30, 1477-1487 (2008).

Senthilkumar, M., M. Madhaiyan, S.P. Sundaram and S. Kannaiyan: Intercellular colonization and growth promoting effects of Methylobacterium sp. with plant-growth regulators on rice (Oryza sativa L. cv CO-43). Microbiol. Res., 164, 92-104 (2009).

Singh, H.P., S. Uma, R. Selvarajan and J.L. Karihaloo: Micropropagation for production of quality banana planting material in Asia-Pacific. Asia-Pacific Consortium on Agricultural Biotechnology (APCoAB), New Delhi, India, p. 92 (2011).

Sousa, C.M., R.P. Santos and R.M. Miranda: Otimizac ão da concentrac, ão dos saisdo meio MS na propagac, ão in vitro de Gérbera, var. 'Ornela' (Optimization of salts concentration of medium MS in the micropropagation of Gerbera, var. 'Ornela'). Agronomia, 40, 52-58 (2006).

Ting, A.S.Y., S. Meon, J. Kadir, S. Radu and G. Singh: Endophytic microorganisms as potential growth promoters of banana. Bio. Control., 53, 541-553 (2008).

Van Huylenbroeck, J.M.: Influence of light stress during the acclimation of in-vitro plantlets. In: Plant production on the threshold of a new century (Eds.: P.C. Struik, W.J. Vredenberg, J.A. Renkema and J.E. Parlevliet). Kluwer Academic Publishers, Dordrecht, NL, pp 451-453 (1994).

Van Huylenbroeck, J.M., H. Huygens and P.C. Debergh: Photoinhibition during acclimatization of micropropagated Spathiphyllum "Petite" plantlets. In-vitro Cell Dev. Biol., 31, 160-164 (1995).

Van Huylenbroeck, J. and P. Debergh: Impact of sugar concentration invitro on photosynthesis and carbon metabolism during ex-vitro acclimatization of Spathiphyllum plantlets. Physiol. Plant., 96, 298-304 (1996). 